\title{
Pengembangan Alat Peraga Pembelajaran Fisika untuk Meningkatkan Keterampilan Proses Sains Mahasiswa Tadris Fisika FATIK IAIN Kendari
}

\author{
Salam L. ${ }^{1}$; Zainuddin ${ }^{2}$; Abbas ${ }^{2}$; Ety Nur Inah² ${ }^{2}$ Jumarddin La Fua $^{2}$ \\ 1) Alumni Prodi Tadris Fisika, Fakultas Tarbiyah dan Ilmu Keguruan (FTIK), Institut Agama Islam Negeri (IAIN) \\ Kendari; \\ 2) Dosen FTIK, IAIN Kendari; \\ Email Korespondensi: zainuddin.zain.fis@gmail.com
}

\begin{abstract}
This research was a special development in the discussion of electronics with the subject of the transformer and power supply. The purpose of this study was to determine the validity, practicality, and effectiveness of a teaching aid that is used in the lecture process to be able to improve students' science process skills. This research was a Research and Development with Pretest-Postest One Group Design. This research was conducted on students of the Physics Tadris and IPA Tadris, Faculty of Tarbiyah and Teacher Training (FTIK) semester IV of the academic year 2018/2019 by using small group (limited) trial samples and large (free) group sample trials. Both samples were each given pretest and posttest treatment. Based on the results of expert assessment and student questionnaire responses to teaching aids that are developed, valid and feasible to be developed. The mean test results of learning outcomes showed an increase in the results of the pretest to posttest on the two samples tested. The results of the t test analysis showed a significant difference between the average before students were given learning treatment, first the teaching aids were validated and declared valid, practical, and effective were used to improve the science process skills of the students of the Physics Department of Physics, FTIK IAIN Kendari.
\end{abstract}

Keywords: Teaching Aids, Science Process Skills

\begin{abstract}
ABSTRAK
Penelitian ini merupakan pengembangan terkhusus pada pembahasan elektronika dengan pokok materi transformator dan power supply. Tujuan penelitian adalah untuk mengetahui valid, praktis, dan efektifnya suatu alat peraga pembelajaran yang digunakan pada proses perkuliahan agar mampu meningkatkan keterampilan proses sains mahasiswa. Penelitian ini merupakan Research and Development dengan desain Pretest-Postest One Group Design. Penelitian ini dilaksanakan pada mahasiswa Tadris Fisika dan Tadris IPA, Fakultas Tarbiyah dan Ilmu Keguruan (FTIK) semester IV tahun akademik 2018/2019 dengan meggunakan sampel uji coba kelompok kecil (terbatas) dan uji coba sampel kelomok besar (bebas). Kedua sampel tersebut masing-masing diberi perlakuan pretest dan postest. Berdasarkan hasil penilaian pakar dan angket tanggapan mahasiswa tehadap alat peraga pembelajaran yang dikembangkan, valid dan layak untuk dikembangkan. Hasil uji rerata hasil belajar menunjukan adanya peningkatan hasil pretest ke postest pada kedua sempel yang diuji coba. Hasil analisis uji t menunjukan adanya perbedaan ratarata yang signifikan antara sebelum mahasiswa diberikan perlakuan pembelajaraan, terlebih dahulu alat peraga pembelajaran divalidasi dan dinyatakan valid, praktis, dan efektif digunakan untuk meningkatkan keterampilan proses sains mahasiswa Tadris Fisika FTIK IAIN Kendari.
\end{abstract}

\section{Kata Kunci: Alat Peraga, Keterampilan Proses Sains}

\section{PENDAHULUAN}

Fisika sebagai bagian dari sains dalam pencarian kebenaranya tidak hanya terbatas melalui kebenaran ilmiah saja, melainkan juga digali dari sumber kebenaran yang lebih lengkap atau komprehensif. Dalam hal ini antara ilmu dan agama difungsikan secara padu, selain bersama-sama untuk menggali kebenaran, masing-masing juga bersifat komplementer. Sebenarnya banyak sekali nilai-nilai spiritual yang dapat ditanamkan dalam pembelajaran fisika karana banyak konsep dan konten fisika yang erat kaitannya dengan nilai-nilai Islam. Misalnya penciptaan langit dan bumi, tata surya, alam semesta dan lain sebagainya yang tentu saja konsep tersebut terkait dengan nilai-nilai Islam. Begitu pula dengan program studi tadris fisika yang berada di IAIN Kendari.

Kurangnya pengembangan media pembelajaran fisika mengakibatkan kurangnya konsentrasi mahasiswa pada saat proses perkuliahan berlangsung. Masalah tersebut disebabkan oleh beberapa faktor antara lain: 1) alat 
laboratorium yang terbatas menyebabkan kurangnya pengembangan media pembelajaran fisika; 2) tidak adanya motivasi untuk mengembangakan media pembelajaran fisika; 3) mahasiswa yang umumnya hanya mampu merangkai alat yang ada dikarenakan kurangnya kemampuan dalam membuat alat/media; 4) mahasiswa yang tidak fokus memperhatikan penjelasan dosen.

Pengembangan atau research \& development merupakan suatu bentuk metode penelitian yang digunakan untuk menghasilkan suatu produk termaksud produk pembelajaran dengan menguji terlebih dahulu keefektifan produk yang dihasilkan (Sugiyono, 2013). Sementara itu, Brog and Gall (2008) mendefinisikan bahwa penelitian pengembangan pendidikan adalah sebuah proses yang digunakan untuk mengembangkan dan memvalidasi produk-produk pendidikan. Sesuai dengan namanya, Research \& development dipahami sebagai kegiatan penelitian yang dimulai dengan research dan diteruskan dengan development. Kegiatan research dilakukan untuk mendapatkan informasi tentang kebutuhan pengguna (needs assement), sedangkan kegiatan development dilakukan untuk menghasilkan perangkat pembelajaran yang akan dikembangkan.

Sebuah produk baru yang dihasilkan dalam penelitian pengembangan minimal harus memenuhi 3 kriteria yaitu valid, praktis dan efektif. Suatu produk atau program dikatakan valid apabila merefleksikan jiwa pengetahuan state of the art of knowledge, yang bisa juga disebut validitas isi. Suatu produk dikatakan praktis apabila orang yang menggunakan produk tersebut menganggap bahwa produk tersebut dapat digunakan (usable). Sedangkan produk tersebut efektif jika produk tersebut memberikan hasil sesuai dengan tujuan yang diterapkan (Asikin, 2011).

Pengembangan adalah suatu proses atau langkah-langkah untuk mengembangkan suatu produk baru atau menyempurnakan produk yang telah ada, yang dapat dipertanggung jawabkan. Untuk dapat menghasilkan produk tertentu digunakan penelitian yang bersifat analisis kebutuhan dan untuk menguji keefektifan produk tersebut agar dapat berfungsi di masyarakat luas. Pengembangan produk adalah peningkatan dan perluasan produk yang ada. Proses pengembangan adalah menciptakan proses baru atau yang ditingkatkan. Research and development merupakan perbaikan/pembaruan (improvement) dan perluasan (extension) dengan menekankan pada kebaruan dan produk nyata (Prasetyo, 2012).

Bahan ajar merupakan seperangkat materi yang disusun secara sistematis baik tertulis maupun tidak sehingga tercipta lingkungan/suasana yang memungkinkan siswa untuk belajar. Penggunaan bahan ajar dalam kelas merupakan suatu alternatif untuk proses pembelajaran yang menitik beratkan pada keaktifan dan pemahaman siswa. Pengembangan bahan ajar ini didukung oleh beberapa hasil penelitian yang menemakan bahwa pembelajaran yang menggunakan bahan ajar efektif meningkatkan hasil belajar siswa. Kelebihan penggunaan bahan ajar adalah mampu menjelaskan sesuatu dengan bahasa yang mudah diterima peserta didik/mahasiswa sesuai dengan tingkat usia dan pengetahuannya. Bahan ajar merupakan salah satu bentuk bahan ajar yang dikemas secara utuh dan sistematis, didalamnya memuat seperangkat pengalaman belajar terencana serta didesain untuk membantu mahasiswa menguasai tujuan yang spesifik. Bahan ajar minimal memuat tujuan pembelajaran, materi/subtansi belajar dan evaluasi (Fatmawati, 2007).

\section{METODE PENELITIAN}

Jenis penelitian ini adalah penelitian pengembangan (research and development) dengan rancangan 4D, yakni; Define, Design, Develop, and Disseminate yang mengadaptasi model penelitian Borg and Gall dengan pengembangan perangkatnya mengadaptasi model pengembangan ADDIE yang meliputi 4 tahapan yaitu tahap analisis, desain, pengembangan, serta implementasi dan evaluasi (Sukardjita, 2015). Penelitian ini dilaksanakan pada Program Studi Tadris Fisika, FTIK, IAIN Kendari, dan subjek uji coba produk hasil penelitian adalah mahasiswa program studi Tadris Fisika semester 4 tahun akademik 2018/2019 yang dilaksanakan dengan waktu penelitian selama 4 (empat bulan). Sedangkan Sumber datanya adalah pakar pendidikan yang terdiri dari dosen yang berpengalaman, yang berperan dalam memberikan data mengenai validitas produk pembelajaran yang meliputi; ahli media dan ahli materi (masing-masing satu orang). Mahasiswa berperan dalam memperoleh data tentang kepraktisan dan efektivitas produk (alat peraga sebagai media pembelajaran). Mahasiswa yang dimaksud adalah mahasiswa program studi Tadris IPA dan Fisika IAIN Kendari yang merupakan sampel pada tahap implementasi produk (eksperimen) terdiri dari 17 orang untuk uji coba sampel kelompok kecil dan 23 orang mahasiswa untuk uji coba sampel kelompok besar.

Penelitian menggunakan desain pretest-posttest one group design, yang pembelajarannya dilaksanakan oleh dosen Elektronika Dasar Semester 4 di Program Studi Tadris Fisika IAIN Kendari. Berdasarkan data tentang kevalidan dan kepraktisan produk (alat peraga pembelajaran elektronika dasar (eldas)) diperoleh melalui instrumen observasi dan kuesioner. 


\section{HASIL PENELITIAN}

Pada saat kegiatan penelitian ini berlangsung, kurikulum yang digunakan pada Program Studi Tadris Fisika FTIK IAIN Kendari adalah kurikulum tahun 2015 yang dimodifikasi menjadi kurikulum Kerangka Kualifikasi Nasional dengan jumlah SKS untuk program strata satu (S1) antara 144-148 SKS. Sebaran jumlah SKS pencapaian kompotensi program studi meliputi: 1) kompetensi utama 90-100 SKS; 2) kompetensi pendukung 30-38 SKS; 3) kompetensi lain 6-12 SKS.

Pada tanggal 18 desember 2018 peneliti melakukan studi pendahuluan, diperoleh beberapa informasi berkaitan dengan kondisi kampus terkhusus pada mahasiswa yang diteliti. Baik mengenai kelebihan maupun kekurangan masing-masing mahasiswa. Data mengenai proses pembelajaran di IAIN Kendari yang selama ini berlangsung, data mengenai mahasiswa dan dosen yang bersangkutan juga sarana dan prasarana yang tersedia. Data-data yang diperoleh dari studi pendahuluan ini dijadikan sebagai landasan bagi pengembangan alat peraga pembelajaran dalam mata kuliah elektronika (arus bolak balik dan trasformator) yang diharapkan dapat meningkatkan keterampilan proses sains mahasiswa.

Pengumpulan data dilakukan dengan menggunakan tes, observasi dan studi dokumenter, serta wawancara. Wawancara dilakukan kepada dosen yang bersangkutan untuk mendapatkan data-data tentang kondisi mahasiswa, tugas dan peran, pandangannya terhadap pembelajaran elektronika yang menjadi tanggung jawabnya, media yang selama ini digunakan, pengembangan keterampilan proses sains mahasiswa, implementasi pembelajaran mulai dari perencanaan, pelaksanaan pembelajaran, dan evaluasi, serta data tentang sarana dan prasarana penunjang perkuliahan yang tersedia di IAIN Kendari seperti buku-buku dan alat penunjang, media belajar serta perpustakaan. Wawancara juga dilakukan kepada mahasiswa sebelum proses pengembangan alat peraga yang bertujuan untuk mendapatkan data tentang pandangan mahasiswa terhadap proses perkuliahan yang selama ini telah dilakukan oleh dosen.

Observasi awal dilakukan pada program studi Tadris Fisika FTIK IAIN Kendari yang dijadikan objek penelitian dengan jumlah responden 23 orang mahasiswa. Tujuan utama observasi ini adalah untuk mengetahui keadaan sebenarnya, untuk mendapatkan gambaran umum tentang proses perkuliahan elektronika, dan untuk mendapatkan informasi tentang faktor pendukung dan penghambat terciptanya pembelajaran elektronika yang kondusif.

\section{Pembelajaran Elektronika pada Prodi Tadris Fisika IAIN Kendari}

Pada program studi Tadris Fisika Fakultas Tarbiyah dan Ilmu Keguruan di IAIN merupakan salah satu jurusan yang kurang diminati. Dosen yang mengajar mata kuliah elektronika di IAIN Kendari berjumlah 1 orang. Dosen tersebut memiliki latar belakang bidang keilmuan jurusan pendidikan fisika dari Universitas Negeri Makassar (UNM) dengan jenjang akhir sebagai Magister Pendidikan (M.Pd.) dan memiliki pengalaman mengajar yang sangat baik.

Perkuliahan elektronika di IAIN Kendari berjalan dengan tertib dan lancar. Dosen mengajar dengan menggunakan metode konvensional yaitu ceramah, tanya jawab dan pemberian tugas. Hal ini dapat dilihat dari peran yang dilakukan oleh dosen selama pembelajaran. Dosen bertindak sebagai sumber tunggal bagi mahasiswa selama berlangsungnya proses perkuliahan. Kegiatan pembelajaran didominasi oleh penyajian materi yang dilakukan oleh dosen dan mahasiswa lebih banyak hanya mendengarkan, mencatat apa yang disampaikan dan dianggap penting oleh dosen serta mnegerjakan tugas yang diberikan oleh dosen, sehingga yang terjadi hanya transfer pengetahuan dari dosen ke mahasiswa.

Setiap saat akan memulai perkuliahan, dosen selalu mengingatkan materi perkuliahan yang dipelajari sebelumnya. Proses perkuliahan berlangsung lebih banyak dengan mengikuti urutan yang ada pada slide, dan tidak dimodelkan dalam konteks yang konkrit. Disamping itu, dosen jarang menyampaikan tujuan perkuliahan yang ingin dicapai dari perkuliahan yang dilakukannya, sehingga mahasiswa menjadi tidak jelas apa yang ingin dicapai dalam perkuliahan tersebut. Artinya, mahasiwa tidak tahu kriteria dan prosedur keberhasilan perkuliahan yang digunakan oleh dosen.

Media yang digunakan dalam proses perkuliahan elektronika kurang dimanfaatkan termasuk pemanfaatan laboratorium fisika. Pola pembelajaran yang kurang kondusif, tidak variatif, tidak mengajak mahasiswa untuk berfikir secara kreatif, dan lebih menekankan pengajaran kemampuan kognitif nampaknya disebabkan oleh beberapa faktor, yakni: 1) tidak adanya motivasi dosen dalam menerapkan berbagai pendekatan dalam perkuliaan; 2) kurangnya fasilitas perkuliahan dalam melakukan berbagai inovasi dalam proses perkuliahan; 3) materi elektronika yang harus diselesaikan dalam standar isi cukup tinggi. 


\section{Validasi Alat Peraga oleh Pakar}

Pengembangan alat peraga yang dikembangkan pada materi transformator dikonsultasikan dan dinilai terlebih dahulu kepada validator media yakni guru pembelajaran fisika SMA Negeri 13 Konawe Selatan, Sitti Ramadan, S.Pd.. Penilaian ini bertujuan untuk mengetahui kelayakan dari alat peraga tersebut apabila digunakan sebagai media pembelajaran. Adapun hasil validasi oleh pakar media pembelajaran dapat dilihat pada tabel 1 berikut.

Tabel 1. Persentasi Aspek Kelayakan Alat Peraga

\begin{tabular}{|c|c|c|c|}
\hline No. & Aspek Kelayakan & Persentase (\%) & Kriteria \\
\hline 1 & Validator materi 1 & 89 & Sangat layak \\
\hline 2 & Validator materi 2 & 86 & Sangat layak \\
\hline 3 & Validator media & 98.33 & Sangat layak \\
\hline & Rata-rata & 91,11 & Sangat lavak \\
\hline
\end{tabular}

Tabel di atas menunjukan bahwa skor persentase aspek tampilan yang diberikan oleh validator materi 1 dan 2 adalah $89 \%$ dan 86\%. Kriteria aspek penilaian validator media memperoleh persentase sebesar 98,33\%. Berdasarkan skala likert skor persentase, maka media pembelajar yang dikembangkan jika dirata-ratakan ntuk ketiga validator ialah $91,11 \%$ dan dapat dikategorikan sangat baik sehingga layak digunakan untuk proses perkulliahan.

Berdasarkan kriteria yang harus dipenuhi dalam pengembangan sebuah produk adalah produk yang dihasilkan haruslah praktis. Suatu produk dikatakan praktis apabila produk tersebut bersifat usable atau dapat digunakan sesuai tujuan pengembangan produk. Dalam penelitian ini, produk yang dikembangkan adalah media pembelajaran yang diberi nama dengan alat peraga pembelajaran.

Tabel 2. Data Hasil Observasi Keterlaksanaan Alat Peraga

\begin{tabular}{|c|c|c|c|c|c|c|c|c|c|}
\hline \multirow{3}{*}{ Aspek Yang Diukur } & \multicolumn{9}{|c|}{ Nilai Observasi/Pertemuan } \\
\hline & \multicolumn{2}{|c|}{ Pertemuan1 } & \multirow{2}{*}{$\begin{array}{c}\text { Rerata- } \\
1\end{array}$} & \multicolumn{2}{|c|}{ Pertemuan2 } & \multirow{2}{*}{ Rerata-2 } & \multicolumn{2}{|c|}{ Pertemuan3 } & \multirow{2}{*}{ Rerata-3 } \\
\hline & 1 & 2 & & 1 & 2 & & 1 & 2 & \\
\hline Kegiatan Awal & 1.5 & 1.5 & 1.5 & 1.5 & 1.75 & 1.63 & 1.75 & 2 & 1.86 \\
\hline Kegiatan Inti & 1.6 & 1.6 & 1.6 & 1.8 & 1.65 & 1.725 & 1.8 & 1.8 & 1.8 \\
\hline Kegiatan Akhir & 1.5 & 1.5 & 1.5 & 1.5 & 2 & 1.75 & 2 & 2 & 2 \\
\hline Jumlah & 4.6 & 4.6 & 4.6 & 4.8 & 5.4 & 5.105 & 5.5 & 5.8 & 5.66 \\
\hline Rerata/ Observer & 1.5 & 1.5 & 1.5 & 1.6 & 1.8 & 1.7 & 1.85 & 1.933 & 1.8867 \\
\hline Rerata/ Pertemuan & \multicolumn{3}{|c|}{1.55} & \multicolumn{3}{|c|}{1.7} & \multicolumn{3}{|c|}{1.89} \\
\hline $\begin{array}{c}\text { Rerata } \\
\text { Keterlaksanaan }\end{array}$ & \multicolumn{9}{|c|}{1.71} \\
\hline
\end{tabular}

Keterangan

$$
\begin{aligned}
& 1,5 \leq \mathrm{V} \leq 2,0 \\
& 0,5 \leq \mathrm{M}<1,4 \\
& 0,0 \leq \mathrm{M}<0,4
\end{aligned}
$$

Terlaksana Seluruhnya
Terlaksana Sebahagian
Tidak Terlaksana

Berdasarkan tabel uraian pertemuan di atas, dapat diartikan bahwa penggunaan alat peraga pembelajaran alam proses perkuliahan sangat efektif membantu mahasiswa dalam memahami materi yang diajarkan.

Keefektifan merupakan kriteria yang harus dipenuhi hasil penembangan sebuah produk. Efektif menunjukkan kemampuan sebuah produk dalam mencapai tujuan dikembangkannya. Pengembangan produk dikatakan efektif jika produk tersebut memberikan hasil yang sesuai dengan tujuan yang ditetapkan sebelumnya. Pada penelitian pengembangan ini, produk yang dikembangkan adalah alat peraga yang merupakan panduan tentang materi yang sedang dibahas pada proses perkuliahan berlangsung.

Tabel 3. Data Mahasiswa Pada Sampel Uji Coba

\begin{tabular}{|c|c|r|r|r|r|r|r|r|}
\hline \multicolumn{2}{|c|}{} & \multicolumn{7}{c|}{ Statistik Deskriptip } \\
\hline \multicolumn{2}{|c|}{ Parameter } & N & Jarak & Minimum & Maksimum & Berarti & Std. Devisi & Perbedaan \\
\hline $\begin{array}{c}\text { Nilai kelompok } \\
\text { besar (luas) }\end{array}$ & Tes awal & 23 & 21.00 & 56.00 & 77.00 & 68.173 & 5.96697 & 35.605 \\
\cline { 2 - 10 } & Tes akhir & 23 & 12.00 & 80.00 & 92.00 & 85.391 & 3.75063 & 14.067 \\
\hline $\begin{array}{c}\text { Nilai kelompok } \\
\text { kecil (terbatas) }\end{array}$ & Tes awal & 12 & 20.00 & 60.00 & 80.00 & 70.416 & 7.82140 & 61.174 \\
\cline { 2 - 9 } & Tes akhir & 12 & 20.00 & 75.00 & 95.00 & 83.333 & 7.78499 & 60.606 \\
\hline
\end{tabular}


Berdasarkan data keterampilan proses sains mahasiswa yang direkam melalui instrument tes, dan kemudian dianalsis menggunakan uji-t berpasangan (paired sample t test). Berdasarkan hasil uji-t berpasangan tersebut, dapat dilihat rata-rata perbedaan antara nilai pretes dan postes pada sampel kelompok kecil ialah sebesar 12.917. Tanda minus (-) berarti nilai keterampilan proses sains mahasiswa sudah diberi perlakuan dengan menggunakan alat peraga pembelajaran (media pembelajaran) lebih besar dibandingkan dengan nilai keterampilan proses sains mahasiswa sebelum diberikan perlakuan (sebelum adanya alat peraga). Sehingga dapat disimpulkan bahwa, peningkatan nilai keterampilan proses sains mahasiwa setelah diberikan perlakuan dengan simpangan rata-rata peningkatan yang menyebar pada seluruh sampel ialah sebesar 4,981. Sedang nilai $t_{\text {hil }}=8,983>t_{t}=2,228$. Pada taraf $\alpha=$ 0,05 , dan probabilitas $(\rho)$ Sig. $=0.000<\alpha=0,05$.

\section{PEMBAHASAN}

Penelitian dan pengembangan (research and development) merupakan salah satu metode dalam mengembangkan sebuah produk sekaligus memvalidasi produk yang dihasilkan, termasuk produk pembelajaran. Penelitian dan pengembangan ini dilaksanakan denganbeberapa tahapan yakni dimulai mengidentifikasi potensi dan masalah yang berada pada mahasiswa Program Studi Tadris Fisika FTIK IAIN Kendari, seperti kriteria keterampilan proses sains mahasiswa yang masih rendah dan banyak potensi yang bisa digunakan sebagai media pembelajaran yang tidak termanfaatkan. Peneliti mendesain pengembangan alat peraga pembelajaran yang mampu meningkatkan keterampilan proses sains mahasiswa. Pengembangan produk alat peraga ini dipilih peneliti dikarenakan alat peraga tersebut mampu mempermudah mahasiswa dalam memahami pokok pembahasan serta mampu meningkatkan kemampuan mahasiswa dalam mendesain alat secara mandiri. Penggunaan alat peraga tersebut sangat baik diterapkan kepada mahasiswa karena memiliki kelebihan, salah satunya mahasiswa mampu berfikir kreatif serta mendapat hal baru dalam pembelajaran.

Pengembangan produk alat peraga ini dipilih peneliti dikarenakan alat peraga tersebut mampu mempermudah mahasiswa dalam memahami pokok pembahasan serta mampu meningkatkan kemampuan mahasiswa dalam mendesai alat secara mandiri. Materi transformator dan prinsip kerja pada power supply merupakan materi dengan sumber belajar yang mudah ditemukan dalam kehidupan sehari-hari. Materi ini sangat berhubungan erat dengan kehidupan mahasiwa, mengingat kemajuan teknologi makin berkembang pesat. Pengujian alat peraga yang dikembangkan dpat dikatakan layak dipergunakan setelah memenuhi tiga kriteria yakni, valid, praktis, dan efektif. Validasi produk dilakukan pada setiap tahap pengembangan sebagaimana telah diuraikan sebelumnya, sedangkan uji kepraktisan dan keefektifan produk diuji paada tahap impelentasi dan evaluasi.

Berdaasarkan kriteria pada skala likert menunjukan bahwa perolehan nilai yang cukup baik dengan rata-rata 91,11\%. Hal ini menunjukan bahwa alat peraga pembelajaran yang dikembangkan sebagai media pembelajaran elektronika dasar mampu memberikan nilai tambahan serta manfaat yang cukup signifikan pada mahasiswa sebagai bahan untuk belajar mandiri. Kevalidan alat peraga pembelajaran ini, diperoleh berdasarkan hasil penilaian dari validator. Berdasarkan hasil penilaian dari validator, menunjukan bahwa keseluruhan komponen yang dinilai dalam alat peraga dinyatakan sangat valid. Sedangkan untuk instrumen berupa lembar observasi keterlaksanaan alat peraga pembelajaran dan angket respon mahasiswa terhadap alat peraga dinyatakan valid. Data kepraktisan perangkat diperoleh dari analisi data keterlaksanaan perangkat pembelajaran hasil uji coba oleh pengamat. Alat peraga dikatakan praktis, jika memenuhi dua kriteria, yaitu 1) alat peraga yang dikembangkan dapat ditetapkan menurut penilaian para ahli dan praktis; 2) alat peraga yang dikembangkan dapat digunakan atau diterapkan di lapangan. Hal ini ditunjukkan oleh hasil validasi untuk instrumen lembar observasi keterlaksanaan alat peraga berada pada kategori valid dan dapat digunakan dalam revisi kecil. Kriteria alat peraga pembelajaran dinilai berdasarkan respon mahasiswa yang baik terhadap alat peraga pembelajaran yang digunakan untuk melihat hasil belajar mahasiswa. Beberapa kriteria keefektifan seperti yang telah dikemukakan, diperoleh alat peraga yang efektif jika dilihat pada kriteria dapat dinyatakan bahwa mahasiswa dapat memberikan respon yang sangat positif sebesar 87,33 pada sampel uji kelompok kecil dan 87,78 pada sampel uji coba kelompok besar, yang memberikan respon positif terhadap alat peraga pembelajaran elektronika. Setelah dilakukan uji coba kriteria di atas sudah terpenuhi sehingga diperoleh alat peraga pembelajaran yang efektif.

\section{KESIMPULAN}

Berdasarkan hasil analisis data, pengujian hipotesis, dan pembahasan hasil penelitian, dapat ditarik kesimpulan ialah : 1) Hasil uji kevalidan alat peraga pembelajaran elektronika pada program studi Tadris Fisika FTIK IAIN Kendari adalah telah memenuhi kriteria valid. Nilai rata-rata kevalidan alat peraga adalah $91,11 \%$ dengan kriteria kevalidan dinyatakan dalam kategori sangat valid; 2) Pengembangan alat peraga pembelajaran 
dikatakan sebagai produk dengan nilai kepraktisan 1.7 yang terkategori sangat baik untuk dapat dipergunakan sebagai media pembelajaran; 3) Pengunaan alat peraga pembelajaran fisika dikatakan sebagai produk efektif karena dapat meningkatkan nilai dan keterampilan mahasiswa.

\section{DAFTAR PUSTAKA}

Asikin,M., Cahyono. A. N. (2011). Peneltian dan Pengembangan dalam Bidang Pendidikan. FMIPAUnnes: http://adinegara.com/wpcontent/uploads/2011/6/makala-R-n-D.pdf, (diakses 06 desember 2018).

Asnawir dan M. Basyiruddin Usman (2002). Media Pembelajaran. Jakarta: Ciputat Pers.

Azhar Arsyad (2005). Media Pembelajaran. Jakarta: PT. Raja Grafindo Persada.

Borg, W. R. and Gall, M. D. (2008). Educasitional Research: An Introduction. London: Longman, Inc.

Departemen Pendidikan dan Kebudayaan (2002). Kamus Besar Bahasa Indonesia. Jakarta: Balai Pustaka.

Depdiknas (2003). Undang-Undang Republik Indonesia Tahun 2003 tentang Sistem Pendidikan Nasional. Jakarta: Dirjen Pendidikan Dasar dan Menengah.

Djamarah, Syaiful Bahri dan Aswan Zain (2006). Strategi belajar Mengajar. Jakarta: PT. Rineka Cipta.

Douglas C. Giancoli (2001). Fisika Edisi 5. Jakarta: Erlangga.

Fatmawati, L. (2012). Pengembanahan Bahan Ajar Modul Elektrokimia Untuk Siswa SMA Kelas XII Dengan Pendekatan Inkuiri Terbimbing. Diseratai Dan Tesis Program Pascasarjana.

Kemdiknas (2014). Pedoman Penulisan Modul. Jakarta: Direktorat Pendidikan Menengah Kejuruan.Direktorat Jendral Pendidikan Dasar Dan Menengah.

Koselen, S. W. (2007). Electro Dasar. Http://Elektronika-Elektronika.Blogspot.Com

Muhaimin (2002). Paradigma Pendidikan Islam Upaya Mengefektifkan Pendidikan Agama Islam Di Sekolah. Bandung: PT Remaja Rosda Karya.

Musfiqon (2002). Pengembangan Media \& Sumber Pembelajaran. Jakarta: Prestasi Pustaka.

Oemar Hamalik (2003). Kurikulum dan Pembelajaran. Jakarta: Bumi Aksara, 2003.

Prasetyo, K., Zuhdan (2012). Research and Development: Pengembangan Berbasis Penelitian. Surakarta: program pascasarjana universitas negeri sebelas maret.

Pressman, Abrham (1999). Switching Power Supply Desaign. New York: Mc Graw.

Putra, Nusa (2015). Researc \& Development, Penelitian Dan Pengembangan: Suatu Pangantar. Jakarta: PT Raja Grafindo.

Rafiqah (2013). Pengembangan Perangkat Pembelajaran Fisika Berbasis Konstruktivisme Setting Kooperatif. Tesis Tidak Diterbitkan. Makassar: UNM.

Riny Sulistiowati, Dedi (2012). Perancanag Sistem Prototype Sistem Kontrol.Jurnal Iptek Vol. 16 No. 1. Diakses pada Mei 2012.

Santiaya, I Wayan (2007). Landasan Konseptual Media Pembelajaran. Klungkung.

Sugiyono (2012). Metode Penelitian Kuantitatif, Kuantitatif dan $R \& D$. Bandung: Alfabeta. 
Sukmadinata, N. S. (2011). Metode Penelitian Pendidikan. Cet. VII. Bandung: PT Remaja Rosdakarya.

Winarti (2015). Jurnal "Pengembangan Perangkat Pembelajaran Fisika Bermuatan Integrasi Islam-Sains untuk Menanamkan Nilai-Nilai Spiritual Siswa Madrasah Aliyah, Vol. 1 No. 2, (September 2015) http://ejournal.ikippgrimadiun.ac.id/index.php/JPFK (Diakses 28 Oktober 2018). 